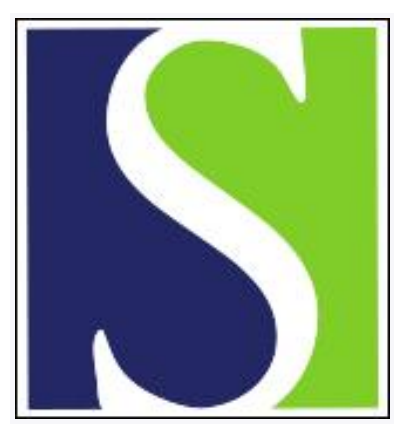

Scand J Work Environ Health 2004;30(3):223-233

https://doi.org/10.5271/sjweh.783

Issue date: Jun 2004

Scientific production and international collaboration in occupational health, 1992-2001

by Navarro A, Martín M

Affiliation: Laboratori de Bioestadística i d`Epidemiologia, Facultat de Medicina, Universitat Autònoma de Barcelona, 08193 Cerdanyola del Ballés, Barcelona, Spain. albert.navarro@uab.es

The following articles refer to this text: 2007;33(4):241-243; SJWEH

Supplements 2009;(7):41-47; 2015;41(3):294-298

Key terms: bibliometrics; international collaboration; occupational health; scientific production

This article in PubMed: www.ncbi.nlm.nih.gov/pubmed/15250651

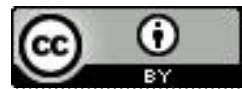




\title{
Scientific production and international collaboration in occupational health, 1992-2001
}

\author{
by Albert Navarro, BSC,1,2 Miguel Martín, PhD ${ }^{1,2}$
}

Navarro A, Martín M. Scientific production and international collaboration in occupational health, 1992-2001. Scand J Work Environ Health 2004;30(3):223-233.

\begin{abstract}
Objectives The objectives of the present study were twofold, to describe international scientific production in occupational health and to examine international collaboration in this discipline.

Methods A bibliometric study was carried out, using Science Citation Index, in order to evaluate the articles published during the period 1992-2001 in eight representative occupational health journals. Scientific production, collaborative profiles for each country, and the significant relationships established between countries are reported. Results One or more institutions in the United States had contributed to over $40 \%$ of the articles examined. The United States was followed by the United Kingdom (9.15\%) and then Sweden (8.65\%). When population size effects were eliminated, the Scandinavian countries proved to be the leading producers. After correction for gross domestic product, there was an increase in the ranking of apparently scientifically modest countries. The Scandinavian countries remained high. In terms of international collaboration in general, there was an inverse relationship between the production of a country and the proportion of articles co-authored with institutions in other countries. Finally, the significant relationships between countries permitted the identification of up to six large collaboration nuclei.

Conclusions The high absolute and relative Scandinavian production is suggestive of the great importance of occupational health in these countries. Access to publication by more modest countries, scientifically speaking, is observed to occur through collaboration with the high-production countries. In this sense, it would seem necessary to study the basis underlying these relationships. Finally, the characterization of the collaborative nuclei does not differ greatly from what was expected.
\end{abstract}

Key terms bibliometrics.

Ten years have passed since the World Health Organization (WHO) (1), in its European regional program "Health for All in the Year 2000" established a series of objectives to be reached by that date. One of these objectives, the 25th, proposed improving the health of workers in all member states through healthier work environments, the reduction of occupational diseases and accidents, and the promotion of workers' well-being. Among the nine points to be developed for the achievement of this aim, one proposed the development and improvement of occupational health information systems and another promoted cooperation among national and international organisms and institutions.

The point, as some authors have observed, is that modern science has always been linked with the diffusion of knowledge and cooperation between specialists (2). Thus it appears necessary to evaluate who publishes in the field of occupational health and how relationships are established between those who publish.

For this purpose, the bibliometric viewpoint is useful as long as it is not forgotten that indicators elaborated by this means represent an incomplete view of reality (3). One of the favorite topics in bibliometrics is the study of scientific production and collaboration.

An examination of scientific production permits us to identify the authors, institutions, or countries most involved in research and publication in relation to some particular topic. Obviously the production does not depend solely on interest, but is also influenced by many other factors, including the availability of economic, human, and material resources, as well as scientific policy.

Scientific collaboration is the study of the relation established between authors or institutions through the joint signing of scientific documents. Thus it is understood to

1 Laboratori de Bioestadística i d'Epidemiologia. Facultat de Medicina. Universitat Autònoma de Barcelona, Barcelona, Spain.

2 Grups de Recerca d'Amèrica i d'Àfrica Llatines (GRAAL).

Reprint requests to: Mr Albert Navarro, Laboratori de Bioestadística i d'Epidemiologia, Facultat de Medicina, Universitat Autònoma de Barcelona, 08193 Cerdanyola del Vallès, Barcelona, Spain. [E-mail: albert.navarro@uab.es] 
involve two or more scientists, or two or more institutions, contributing their efforts and intellectual and physical resources (4). If the work is shared by researchers (or institutions) from different countries, we can speak of international scientific collaboration. Scientific collaboration is the consequence of the constant process of professionalizing science (5). The growing multidisciplinarity and complexity of research (4) makes cooperation between experts necessary even though such cooperation is also promoted by the desire of scientists to increase their knowledge through the interchange of their abilities and data, and the impact on professional recognition (6). Globalization makes this process perceptible between authors and centers of different countries, thanks to the continual development of means of transport and, particularly, means of communication. Another question that can affect international collaboration is how the wealthy countries set up their programs of cooperation with poor countries.

Medicine has been one of the most receptive fields in work of this type. In 1990, Medical Subject Headings, a thesaurus used by Medline to represent the subject matter of the documents it indexes, coined the term "bibliometrics" to refer to publications employing this methodology. In that year (1990) eight documents were indexed under this term, representing 1.8 per 100000 documents indexed by Medline that year. Five years later, the corresponding figure was 9.6, and, in 2000, it had increased to 19.0 per 100000 .

The situation differs however when we examine the penetration of bibliometrics into occupational health literature. Between 1990 and 2002, only 10 documents referring to occupational health were indexed under the bibliometrics heading (7-16). Most of these articles dealt with very specific aspects without investigating either overall scientific production or international collaboration.

These then are precisely the aims of the present study, to describe scientific production in the field of occupational health at the international level and to examine international scientific collaboration in this field.

\section{Material and methods}

\section{Bibliographic database used to capture the information}

The information analyzed was obtained from Science $\mathrm{Ci}$ tation Index (SCI), a multidisciplinary database maintained by the Institute for Scientific Information (ISI) in Philadelphia. SCI indexes some 3700 journals and uses the resulting data in its publication Journal Citation Reports (JCR), in which the famous bibliographic impact factors (BIF) appear. It is this fact that provokes interest among researchers to publish in journals indexed by SCI, particularly in those with higher BIF values, since, in this way, they increase the possibilities of international diffusion of their work. Furthermore, SCI combines certain characteristics that no other bibliographic database provides entirely. The most noteworthy are that it (i) guarantees indexing of all documents published in the journals it includes, (ii) allows the study of collaboration between groups, thanks to the inclusion of affiliation details of all signing authors, (iii) allows an analysis of citations, since it records references made by the indexed documents, and (iv) it processes the information of particular fields with the aim of standardizing content as far as possible and thus facilitating retrospective analysis of this information. As a result, SCI is considered, in most cases, to be the database currently most suited to the realization of bibliometric studies (17).

Records of interest were recovered by querying the database on the CD-ROMs corresponding to the years 1992 through 2002. It was necessary to use the CD-ROM for 2002 because of the problem of time lag (ie, documents published in a given year may possibly not be included until the following year).

\section{Journals chosen}

The source journals for the articles examined were selected with the intention of producing a representative sample of international scientific production in the field of occupational health. The criteria for selection consisted of choosing journals included in the SCI category "Public, environmental \& occupational health" (in order to guarantee international diffusion), and which were, at the same time, classified in Index Medicus under the category of "Occupational Medicine" (in order to guarantee their specificity of subject). The following journals were included that satisfied these conditions: American: American Industrial Hygiene Association Journal (AIHAJ), American Journal of Industrial Medicine (Am J Ind Med), Archives of Environmental Health (Arch Environ Health), Journal of Occupational and Environmental Medicine (J Occup Environ Med); British: The Annals of Occupational Hygiene (Ann Occup Hyg), and Occupational and Environmental Medicine (Occup Environ Med); Scandinavian: Scandinavian Journal of Work, Environment \& Health (Scand J Work Environ Health); and German: International Archives of Occupational and Environmental Health (Int Arch Occup Environ Health).

\section{Studied documents}

Articles published during the period 1992-2001 in the chosen journals were chosen for study. The selection of articles, but not other types of documents (letters, editorials, reviews, etc), was due to the fact that it is particularly the articles that reflect the transmission of the original research that contributes to the accumulation of knowledge by the scientific community. 


\section{Analyzed indicators}

With respect to scientific production, the absolute and relative frequencies of articles, the mean number of authors and institutions involved in the work per article, and the frequencies weighted by population (number of inhabitants) and economic parameters [gross domestic product (GDP)] were used to eliminate the effects of size and the availability of resources in each country and thus facilitate comparability between countries. Data on a country's population and GDP, referring to averages for the period 1991-2000, were obtained from the World Bank (18).

Two determinants of scientific collaboration were employed, a collaboration profile and a proximity index. To establish a collaboration profile for each country, we calculated the percentage of articles with no collaboration (only one author or only one institution), the percentage of national collaboration (more than one author belonging to more than one institution in the same country), and the percentage of international collaboration (authors from institutions in different countries). The proximity index was constructed as an index of multidimensional similarity that explored the intensity of relationships between two countries, taking into account the existence of other countries. It was based on a comparison between the observed collaboration between two countries and the expected collaboration, the latter being the number of co-authored articles between the two countries that would have been observed if international collaboration between all the countries were random. The expected collaboration was calculated using a quasi-independent model. The interpretation of the proximity index is simple. A value greater than 1 means that the relationship between the two coun- tries is higher than expected; in other words, there is a degree of collaboration not attributable solely to chance. A value of less than 1 indicates fewer articles co-authored between the two countries than expected. Other similarity indices exist (Salton, Jaccard) (6), but they are bidimensional (study relation between two countries without taking others into consideration) and they tend to underestimate the relations between pairs of countries if one member is scientifically "large" and the other is "small".

In order to guarantee that the obtained proximity indices were consistent, we only considered relations between countries that had jointly produced more than one article. To the same end, we decided to study in isolation only the countries with a minimum of 10 articles with international collaboration. The other countries were grouped in accordance with a classification facilitated by UNESCO (19).

\section{Results}

During the period under study the journals included in the analysis published 9892 documents, of which $77.5 \%$ were articles. The distribution by journal and document type is shown in table 1.

Figure 1 shows the total number of documents, and articles, distributed by the country or region of the publisher. Note that more than $50 \%$ of the publications were published by North American journals.

The 7668 articles accumulated a total of 31412 signatures of authors and 17767 addresses of institutions. In both figures obviously, some authors and addresses are repeated.

Table 1. Distribution of documents by type and journal.

\begin{tabular}{|c|c|c|c|c|c|c|c|c|c|c|c|c|c|c|c|c|c|c|c|c|c|c|c|c|c|c|c|c|}
\hline \multirow[t]{3}{*}{ Journal } & \multicolumn{28}{|c|}{ Type of document } \\
\hline & \multicolumn{2}{|c|}{ Article } & \multicolumn{2}{|c|}{$\begin{array}{l}\text { Biblio- } \\
\text { graphy }\end{array}$} & \multicolumn{2}{|c|}{$\begin{array}{l}\text { Bio- } \\
\text { graph- } \\
\text { ical- } \\
\text { item }\end{array}$} & \multicolumn{2}{|c|}{$\begin{array}{l}\text { Cor- } \\
\text { rec- } \\
\text { tion }\end{array}$} & \multicolumn{2}{|c|}{$\begin{array}{l}\text { Dis- } \\
\text { cus- } \\
\text { sion }\end{array}$} & \multicolumn{2}{|c|}{$\begin{array}{l}\text { Edito- } \\
\text { rial- } \\
\text { mate- } \\
\text { rial }\end{array}$} & \multicolumn{2}{|c|}{$\begin{array}{l}\text { Edito- } \\
\text { rial }\end{array}$} & \multicolumn{2}{|c|}{ Letter } & \multicolumn{2}{|c|}{$\begin{array}{l}\text { News- } \\
\text { item }\end{array}$} & \multicolumn{2}{|c|}{ Note } & \multicolumn{2}{|c|}{ Reprint } & \multicolumn{2}{|c|}{ Review } & \multicolumn{2}{|c|}{$\begin{array}{l}\text { Soft- } \\
\text { ware- } \\
\text { review }\end{array}$} & \multicolumn{2}{|c|}{ Total } \\
\hline & $\mathrm{N}$ & $\%$ & N & $\%$ & $\mathrm{~N}$ & $\%$ & $\mathrm{~N}$ & $\%$ & $\mathrm{~N}$ & $\%$ & $\mathrm{~N}$ & $\%$ & $\mathrm{~N}$ & $\%$ & $\mathrm{~N}$ & $\%$ & $\mathrm{~N}$ & $\%$ & $\mathrm{~N}$ & $\%$ & $\mathrm{~N}$ & $\%$ & $\mathrm{~N}$ & $\%$ & $\mathrm{~N}$ & $\%$ & $\mathrm{~N}$ & $\%$ \\
\hline AIHAJ & 904 & 68.3 & - & 0.0 & 46 & 3.5 & 13 & 1.0 & - & 0.0 & 96 & 7.3 & 56 & 4.2 & 112 & 8.5 & - & 0.0 & 65 & 4.9 & - & 0.0 & 26 & 2.0 & 6 & 0.5 & 1324 & 13.4 \\
\hline Am J Ind Med & 1490 & 80.8 & - & 0.0 & 11 & 0.6 & 18 & 1.0 & - & 0.0 & 42 & 2.3 & 18 & 2.5 & 160 & 8.7 & - & 0.0 & 78 & 4.2 & - & 0.0 & 21 & 1.1 & - & 0.0 & 1844 & 18.6 \\
\hline $\begin{array}{l}\text { Ann Occup } \\
\text { Hyg }\end{array}$ & 568 & 79.4 & - & 0.0 & 12 & 1.7 & 7 & 1.0 & - & 0.0 & 29 & 4.1 & 18 & 2.5 & 55 & 7.7 & - & 0.0 & 18 & 2.5 & - & 0.0 & 7 & 1.0 & 1 & 0.1 & 715 & 7.2 \\
\hline $\begin{array}{l}\text { Arch Environ } \\
\text { Health }\end{array}$ & 619 & 83.8 & - & 0.0 & 4 & 0.5 & 9 & 1.2 & - & 0.0 & 24 & 3.2 & 20 & 2.7 & 53 & 7.2 & - & 0.0 & 7 & 0.9 & - & 0.0 & 3 & 0.4 & - & 0.0 & 739 & 7.5 \\
\hline $\begin{array}{l}\text { Int Arch Occup } \\
\text { Environ Health }\end{array}$ & 915 & 91.0 & - & 0.0 & - & 0.0 & 5 & 0.5 & - & 0.0 & 24 & 2.4 & 2 & 0.2 & - & 0.0 & - & 0.0 & 12 & 1.2 & - & 0.0 & 47 & 4.7 & - & 0.0 & 1005 & 10.2 \\
\hline J Occup Med & 1164 & 72.0 & 2 & 0.1 & 13 & 0.8 & 24 & 1.5 & 10 & 0.6 & 49 & 3.0 & 34 & 2.1 & 297 & 18.4 & - & 0.0 & 6 & 0.4 & - & 0.0 & 17 & 1.1 & - & 0.0 & 1616 & 16.3 \\
\hline $\begin{array}{l}\text { Occup Environ } \\
\text { Med }\end{array}$ & 1263 & 75.7 & - & 0.0 & 2 & 0.1 & 15 & 0.9 & - & 0.0 & 20 & 1.2 & 27 & 1.6 & 266 & 15.9 & - & 0.0 & 22 & 1.3 & 8 & 0.5 & 45 & 2.7 & 1 & 0.1 & 1669 & 16.9 \\
\hline $\begin{array}{l}\text { Scand J Work } \\
\text { Environ Health }\end{array}$ & 745 & 76.0 & - & 0.0 & 2 & 0.2 & 12 & 1.2 & - & 0.0 & 82 & 8.4 & 11 & 1.1 & 32 & 3.3 & 9 & 0.9 & 21 & 2.1 & 1 & 0.1 & 65 & 6.6 & - & 0.0 & 980 & 9.9 \\
\hline Total & 7668 & 77.5 & 2 & 0.0 & 90 & 0.9 & 103 & 1.0 & 10 & 0.1 & 366 & 3.7 & 192 & 1.9 & 975 & 9.9 & 9 & 0.1 & 229 & 2.3 & 9 & 0.1 & 231 & 2.3 & 8 & 0.1 & 9892 & 100 \\
\hline
\end{tabular}




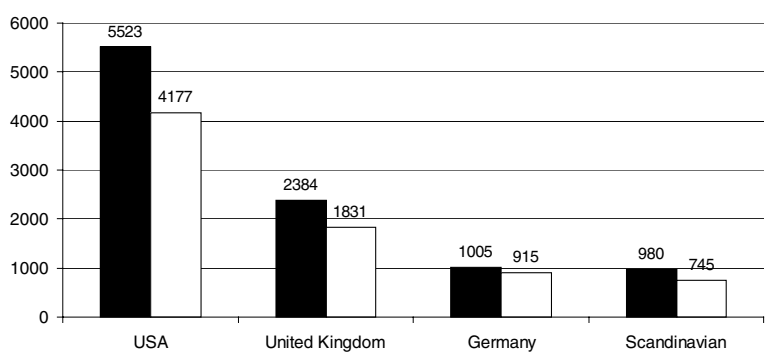

Figure 1. Total number of documents and articles, according to country or region of the publisher. $(\mathbf{\square}=$ number of documents, $\square=$ number of articles)

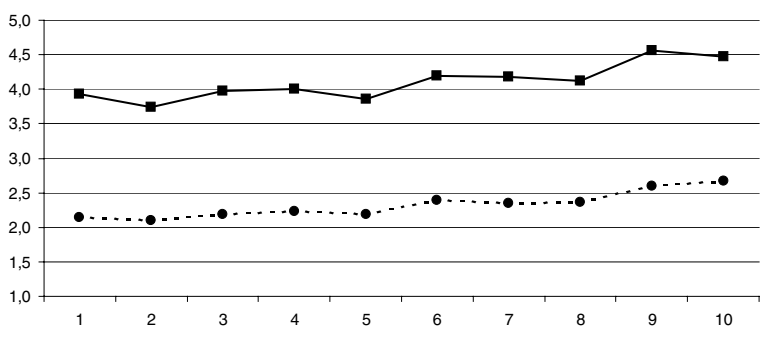

Figure 2. Time trends for the mean numbers of authors and institutions per article. (- - = average institutions per article, $-\mathbf{-}=$ average authors per articles)

The average number of authors per article was 4.10, while that of institutions per article was 2.32. These indicators showed a rising trend over time (figure 2). The author mean increased by $14.2 \%$ between 1992 and 2001, while that of institutions rose by $24.8 \%$.

Only $11.2 \%$ of the articles were the product of only one author, roughly half $(46.5 \%)$ were authored by, at most, three persons, and two in every 100 had 10 or more authors. Surprisingly, 23 articles $(0.3 \%)$ did not specify any author at all. The maximum was 50 authors, corresponding to a multicentric study in the United States. Altogether $35.4 \%$ of the articles were the product of a single institution. Two or fewer institutions figured in approximately two of every three articles, while collaboration of more than 10 institutions occurred for 1 of every 200 articles. The article with the highest participation, 38 institutions, all in the United States, was that with the maximum number of authors. The institution did not appear in $1.4 \%$ of the articles.

\section{Scientific production in occupational health}

Table 2 shows the total number of articles for which the institution is specified, broken down by country to which the institution belonged, as well as the numbers of articles corrected for the country's population and for the GDP. Logically, the corresponding total does not yield the number of articles in which the institution is specified (7560), due to the presence of articles in which institutions in different countries have participated.

Institutions from 84 different countries were involved in the production of the articles studied. In absolute terms, the distribution by country was more or less as would have been expected: those of North America, classical European powers, those of Scandinavia, and Japan head the list. Thus, in $60 \%$ of the articles, at least one of three countries lead production (United States, United Kingdom, Sweden). The institutions of the leading 10 countries (ie, $11.5 \%$ of the total) participated in $86.1 \%$ of all the articles. The United States (US) was the greatest producer in absolute terms, some US institutions being part of the work on $43.6 \%$ of the articles. The presence of Scandinavian countries is also noteworthy, one or more institutions in Sweden, Finland, Denmark, Norway or Iceland figuring in $17.9 \%$ of all articles. The situation is very different for the set of Latin American and Caribbean countries, which only accounted for $1.2 \%$ of the production, that of the central and eastern European countries $(2.5 \%)$ being only slightly higher. Production of all African countries together was $0.97 \%$, although, if we eliminate the contribution of South Africa, it hardly reaches $0.19 \%$ of the total. [South Africa accounts for $80.8 \%$ of the output of Africa as a whole.] Among the Asian countries, Japan, China, and Taiwan stand out, participating in $4.81 \%, 1.69 \%$ and $1.61 \%$ of all articles, respectively. Note that, in table 2 , two countries have been mentioned that have now disappeared as such, the Soviet Union and Czechoslovakia. Both figure in the database as having contributed in the year 1992.

The results, however, are rather different when the population size effect is eliminated. The five biggest producers per inhabitant are now the Scandinavian countries, particularly Sweden and Finland, with production levels far above the rest. Swedish production per inhabitant, for example, is 6 times that of the United States and almost 26 times that of Japan. Canada and The Netherlands have maintained their positions as leaders, while Croatia, Israel, and Singapore have moved up significantly. Estonia, with a more moderate improvement in ranking, has reached the same production per inhabitant as Germany. The United Kingdom and the United States have levels similar to those of Israel and Croatia.

Correction for the GDP of each country produces spectacular changes, Nicaragua heading the list (its seven articles being sufficient to yield a figure of 3.64 articles/billion USD GDP). Other notable increases in rank were found for countries such as Bulgaria and Estonia, occupying the 5th and 10th places, respectively. The leading position occupied by French Guiana should be interpreted with caution, since it had only one published article. More interesting is the position of Croatia, which was already high in the ranking corrected for number of inhabitants. Note that the Scandinavian countries remained among the top 10 of this list. Something similar happened with The Netherlands, Israel, and Canada. The United States moved down to a position similar to that of Belgium or South Africa and was more than 8 times lower than Nicaragua. In general, through GDP correction, we 
Table 2. Number of authors of articles, by country. (GDP = gross domestic product)

\begin{tabular}{|c|c|c|c|c|c|c|c|}
\hline \multirow[t]{2}{*}{ Country } & \multicolumn{3}{|c|}{ Articles } & \multicolumn{2}{|c|}{$\begin{array}{c}\text { Articles per } \\
\text { million } \\
\text { inhabitants }\end{array}$} & \multicolumn{2}{|c|}{$\begin{array}{c}\text { Articles per } \\
\text { billion } \\
\text { US GDP }\end{array}$} \\
\hline & $\mathrm{N}$ & $\%$ & Rank & $\mathrm{N}$ & Rank & $\mathrm{N}$ & Rank \\
\hline United States & 3299 & 43.64 & 1 & 12.37 & 9 & 0.43 & 22 \\
\hline United Kingdom & 692 & 9.15 & 2 & 11.78 & 10 & 0.58 & 15 \\
\hline Sweden & 654 & 8.65 & 3 & 74.41 & 1 & 2.78 & 4 \\
\hline Canada & 489 & 6.47 & 4 & 16.57 & 7 & 0.82 & 12 \\
\hline Finland & 379 & 5.01 & 5 & 74.20 & 2 & 3.22 & 3 \\
\hline Japan & 364 & 4.81 & 6 & 2.90 & 25 & 0.08 & 57 \\
\hline Italy & 347 & 4.59 & 7 & 6.06 & 18 & 0.31 & 29 \\
\hline The Netherlands & 344 & 4.55 & 8 & 22.21 & 6 & 0.94 & 11 \\
\hline Germany & 330 & 4.37 & 9 & 4.05 & 23 & 0.16 & 44 \\
\hline France & 292 & 3.86 & 10 & 5.04 & 20 & 0.21 & 37 \\
\hline Denmark & 236 & 3.12 & 11 & 45.00 & 3 & 1.46 & 7 \\
\hline Norway & 181 & 2.39 & 12 & 41.40 & 4 & 1.29 & 9 \\
\hline $\begin{array}{l}\text { Peoples Republic } \\
\text { of China }\end{array}$ & 128 & 1.69 & 13 & 0.11 & 62 & 0.18 & 40 \\
\hline Taiwan & 122 & 1.61 & 14 & 5.48 & 19 & 0.42 & 25 \\
\hline Australia & 121 & 1.60 & 15 & 6.64 & 17 & 0.33 & 27 \\
\hline Belgium & 103 & 1.36 & 16 & 10.16 & 13 & 0.43 & 22 \\
\hline Switzerland & 69 & 0.91 & 17 & 9.82 & 14 & 0.27 & 32 \\
\hline Israel & 66 & 0.87 & 18 & 11.76 & 11 & 0.76 & 13 \\
\hline Spain & 66 & 0.87 & 18 & 1.68 & 29 & 0.12 & 52 \\
\hline Croatia & 62 & 0.82 & 20 & 13.51 & 8 & 3.57 & 2 \\
\hline South Africa & 60 & 0.79 & 21 & 1.52 & 32 & 0.44 & 21 \\
\hline South Korea & 57 & 0.75 & 22 & 1.26 & 37 & 0.14 & 48 \\
\hline Poland & 41 & 0.54 & 23 & 1.06 & 40 & 0.33 & 27 \\
\hline Singapore & 37 & 0.49 & 24 & 10.28 & 12 & 0.49 & 18 \\
\hline Austria & 33 & 0.44 & 25 & 4.11 & 21 & 0.16 & 44 \\
\hline Mexico & 33 & 0.44 & 25 & 0.36 & 50 & 0.08 & 57 \\
\hline India & 32 & 0.42 & 27 & 0.03 & 75 & 0.09 & 55 \\
\hline New Zealand & 26 & 0.34 & 28 & 7.08 & 16 & 0.50 & 16 \\
\hline Brazil & 25 & 0.33 & 29 & 0.16 & 59 & 0.04 & 68 \\
\hline Bulgaria & 23 & 0.30 & 30 & 2.75 & 26 & 2.06 & 5 \\
\hline Czech Republic & 22 & 0.29 & 31 & 2.13 & 28 & 0.48 & 20 \\
\hline Russia & 16 & 0.21 & 32 & 0.11 & 61 & 0.04 & 68 \\
\hline Greece & 15 & 0.20 & 33 & 1.44 & 34 & 0.14 & 48 \\
\hline Turkey & 14 & 0.19 & 34 & 0.23 & 55 & 0.08 & 57 \\
\hline Iceland & 10 & 0.13 & 35 & 37.16 & 5 & 1.37 & 8 \\
\hline Argentina & 8 & 0.11 & 36 & 0.23 & 56 & 0.03 & 75 \\
\hline Yugoslavia & 8 & 0.11 & 36 & 0.76 & 42 & 0.64 & 14 \\
\hline Nicaragua & 7 & 0.09 & 38 & 1.56 & 31 & 3.64 & 1 \\
\hline Saudi Arabia & 7 & 0.09 & 38 & 0.38 & 49 & 0.05 & 65 \\
\hline Estonia & 6 & 0.08 & 40 & 4.10 & 22 & 1.27 & 10 \\
\hline Hungary & 6 & 0.08 & 40 & 0.59 & 45 & 0.14 & 48 \\
\hline Ireland & 6 & 0.08 & 40 & 1.65 & 30 & 0.09 & 55 \\
\hline Slovakia & 6 & 0.08 & 40 & 1.12 & 39 & 0.36 & 26 \\
\hline United Arab Emirates & 6 & 0.08 & 40 & 2.46 & 27 & 0.15 & 47 \\
\hline Venezuela & 6 & 0.08 & 40 & 0.27 & 52 & 0.08 & 57 \\
\hline Thailand & 5 & 0.07 & 46 & 0.09 & 66 & 0.04 & 68 \\
\hline Egypt & 4 & 0.05 & 47 & 0.07 & 69 & 0.06 & 63 \\
\hline Luxembourg & 4 & 0.05 & 47 & 9.70 & 15 & 0.24 & 35 \\
\hline Chile & 3 & 0.04 & 49 & 0.21 & 57 & 0.05 & 65 \\
\hline Colombia & 3 & 0.04 & 49 & 0.08 & 67 & 0.04 & 68 \\
\hline Costa Rica & 3 & 0.04 & 49 & 0.86 & 41 & 0.25 & 34 \\
\hline Ecuador & 3 & 0.04 & 49 & 0.26 & 54 & 0.18 & 40 \\
\hline Hong Kong & 3 & 0.04 & 49 & 0.48 & 47 & 0.02 & 79 \\
\hline Iran & 3 & 0.04 & 49 & 0.05 & 72 & 0.03 & 75 \\
\hline Lebanon & 3 & 0.04 & 49 & 0.74 & 43 & 0.26 & 33 \\
\hline
\end{tabular}

Table 2. Continued.

\begin{tabular}{|c|c|c|c|c|c|c|c|}
\hline \multirow[t]{2}{*}{ Country } & \multicolumn{3}{|c|}{ Articles } & \multicolumn{2}{|c|}{$\begin{array}{l}\text { Articles per } \\
\text { million } \\
\text { inhabitants }\end{array}$} & \multicolumn{2}{|c|}{$\begin{array}{c}\text { Articles per } \\
\text { billion } \\
\text { US GDP }\end{array}$} \\
\hline & $\mathrm{N}$ & $\%$ & Rank & N & Rank & N & Rank \\
\hline Portugal & 3 & 0.04 & 49 & 0.30 & 51 & 0.03 & 75 \\
\hline Slovenia & 3 & 0.04 & 49 & 1.51 & 33 & 0.18 & 40 \\
\hline Bangladesh & 2 & 0.03 & 58 & 0.02 & 79 & 0.05 & 65 \\
\hline Botswana & 2 & 0.03 & 58 & 1.36 & 35 & 0.43 & 22 \\
\hline Indonesia & 2 & 0.03 & 58 & 0.01 & 81 & 0.01 & 81 \\
\hline Kenya & 2 & 0.03 & 58 & 0.07 & 68 & 0.22 & 36 \\
\hline Kuwait & 2 & 0.03 & 58 & 1.20 & 38 & 0.08 & 57 \\
\hline Lithuania & 2 & 0.03 & 58 & 0.54 & 46 & 0.21 & 37 \\
\hline Nigeria & 2 & 0.03 & 58 & 0.02 & 77 & 0.06 & 63 \\
\hline Ukraine & 2 & 0.03 & 58 & 0.04 & 74 & 0.04 & 68 \\
\hline Uruguay & 2 & 0.03 & 58 & 0.62 & 44 & 0.11 & 53 \\
\hline Vietnam & 2 & 0.03 & 58 & 0.03 & 76 & 0.10 & 54 \\
\hline Armenia & 1 & 0.01 & 68 & 0.27 & 53 & 0.49 & 18 \\
\hline Barbados & 1 & 0.01 & 68 & 3.79 & 24 & 0.50 & 16 \\
\hline Byelarus & 1 & 0.01 & 68 & 0.10 & 63 & 0.04 & 68 \\
\hline Cuba & 1 & 0.01 & 68 & 0.09 & 64 & 0.04 & 68 \\
\hline Ethiopia & 1 & 0.01 & 68 & 0.02 & 78 & 0.17 & 43 \\
\hline French Guiana & 1 & 0.01 & 68 & 1.34 & 36 & 1.70 & 6 \\
\hline Latvia & 1 & 0.01 & 68 & 0.40 & 48 & 0.16 & 44 \\
\hline Pakistan & 1 & 0.01 & 68 & 0.01 & 82 & 0.02 & 79 \\
\hline Philippines & 1 & 0.01 & 68 & 0.01 & 80 & 0.01 & 81 \\
\hline Republic of Georgia & 1 & 0.01 & 68 & 0.19 & 58 & 0.28 & 31 \\
\hline Romania & 1 & 0.01 & 68 & 0.04 & 73 & 0.03 & 75 \\
\hline Sri Lanka & 1 & 0.01 & 68 & 0.05 & 70 & 0.08 & 57 \\
\hline Uganda & 1 & 0.01 & 68 & 0.05 & 71 & 0.20 & 39 \\
\hline Zambia & 1 & 0.01 & 68 & 0.11 & 60 & 0.30 & 30 \\
\hline Zimbabwe & 1 & 0.01 & 68 & 0.09 & 65 & 0.14 & 48 \\
\hline Czechoslovakia & 1 & 0.01 & 68 & - & - & - & - \\
\hline Soviet Union (USSR) & 1 & 0.01 & 68 & - & - & - & - \\
\hline
\end{tabular}

found that central and eastern European countries occupy a rank position that is more relevant, as happens with the African countries. This does not happen, however, with the majority of the countries of Latin America and the Caribbean, except for Nicaragua, which continue to occupy middle positions in the ranking. Taiwan and Singapore became the largest Asian producers, well above Japan and China.

\section{International collaboration in occupational health}

Of the 7560 articles for which some institution was specified, $36.7 \%$ were written without collaboration, $48.9 \%$ with collaboration at the state or national level, and 1086 involved institutions of various countries (ie, international collaboration of $14.4 \%$ ).

The time trends for collaboration are presented in figure 3, where it can be seen that, without distinguishing between national and international, the level of collaboration varies between $58 \%$ and $72.2 \%$ and, moreover, tended to increase, even if somewhat irregularly. This trend is due to international collaboration, which increased clearly and progressively over the 10 years of the study- 


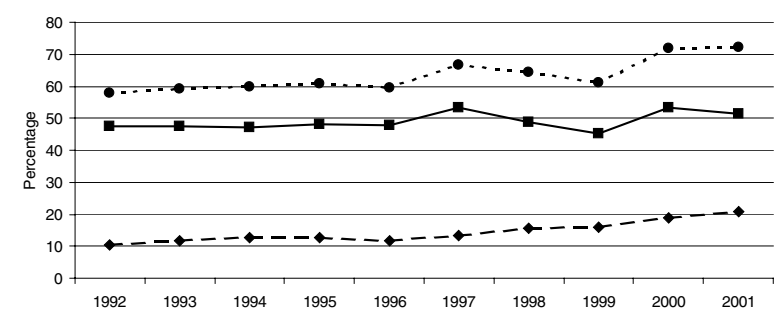

Figure 3. Time trends in collaboration between institutions. [ $-\mathbf{-}=$ national collaboration, $-\bullet-=$ international collaboration, - - - = collaboration (national + international)]

Table 3. Collaboration profiles for each country.

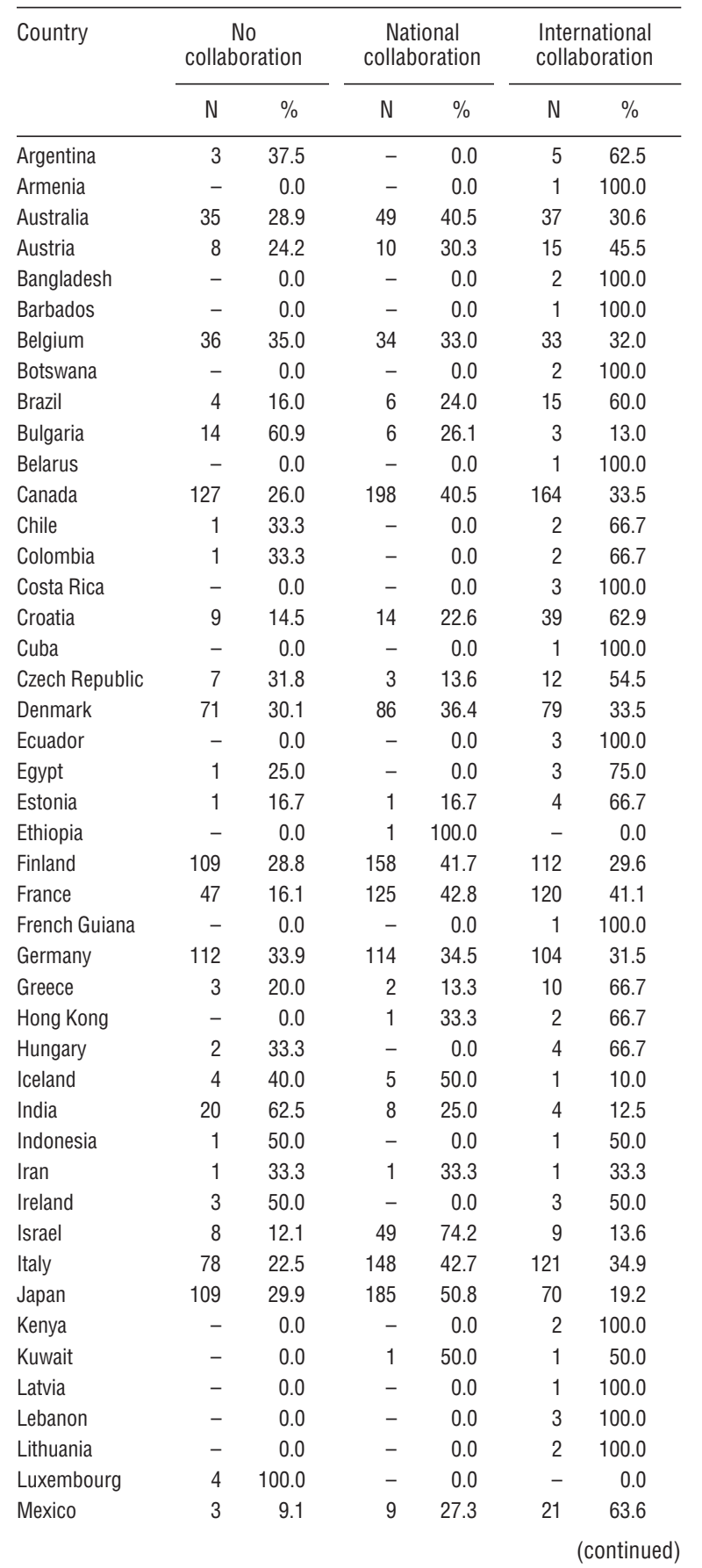

Table 3. Continued.

\begin{tabular}{|c|c|c|c|c|c|c|}
\hline \multirow[t]{2}{*}{ Country } & \multicolumn{2}{|c|}{$\begin{array}{c}\text { Non- } \\
\text { collaboration }\end{array}$} & \multicolumn{2}{|c|}{$\begin{array}{c}\text { National } \\
\text { collaboration }\end{array}$} & \multicolumn{2}{|c|}{$\begin{array}{l}\text { International } \\
\text { collaboration }\end{array}$} \\
\hline & $\mathrm{N}$ & $\%$ & $\mathrm{~N}$ & $\%$ & $\mathrm{~N}$ & $\%$ \\
\hline The Netherlands & 91 & 26.5 & 154 & 44.8 & 99 & 28.8 \\
\hline New Zealand & 7 & 26.9 & 6 & 23.1 & 13 & 50.0 \\
\hline Nicaragua & - & 0.0 & - & 0.0 & 7 & 100.0 \\
\hline Nigeria & 1 & 50.0 & 1 & 50.0 & - & 0.0 \\
\hline Norway & 52 & 28.7 & 79 & 43.6 & 50 & 27.6 \\
\hline Pakistan & - & 0.0 & 1 & 100.0 & - & 0.0 \\
\hline $\begin{array}{l}\text { Peoples Republic } \\
\text { of China }\end{array}$ & 10 & 7.8 & 12 & 9.4 & 106 & 82.8 \\
\hline Philippines & 1 & 100.0 & - & 0.0 & - & 0.0 \\
\hline Poland & 17 & 41.5 & 10 & 24.4 & 14 & 34.1 \\
\hline Portugal & - & 0.0 & - & 0.0 & 3 & 100.0 \\
\hline $\begin{array}{l}\text { Republic of } \\
\text { Georgia }\end{array}$ & - & 0.0 & - & 0.0 & 1 & 100.0 \\
\hline Romania & - & 0.0 & - & 0.0 & 1 & 100.0 \\
\hline Russia & 4 & 25.0 & 2 & 12.5 & 10 & 62.5 \\
\hline Saudi Arabia & 1 & 14.3 & - & 0.0 & 6 & \\
\hline Singapore & 14 & 37.8 & 17 & 45.9 & 6 & 16.2 \\
\hline Slovakia & 1 & 16.7 & 1 & 16.7 & 4 & 66.7 \\
\hline Slovenia & 2 & 66.7 & - & 0.0 & 1 & 33.3 \\
\hline South Africa & 19 & 31.7 & 26 & 43.3 & 15 & 25.0 \\
\hline South Korea & 8 & 14.0 & 9 & 15.8 & 40 & 70.2 \\
\hline Spain & 12 & 18.2 & 21 & 31.8 & 33 & 50.0 \\
\hline Sri Lanka & - & 0.0 & - & 0.0 & 1 & 100.0 \\
\hline Sweden & 187 & 28.6 & 291 & 44.5 & 176 & \\
\hline Switzerland & 21 & 30.4 & 16 & 23.2 & 32 & 46.4 \\
\hline Taiwan & 27 & 22.1 & 69 & 56.6 & 26 & 21.3 \\
\hline Thailand & - & 0.0 & - & 0.0 & 5 & 100.0 \\
\hline Turkey & 5 & 35.7 & 5 & 35.7 & 4 & 28.6 \\
\hline $\begin{array}{l}\text { United Arab } \\
\text { Emirate }\end{array}$ & - & 0.0 & 1 & 16.7 & 5 & 83.3 \\
\hline Uganda & - & 0.0 & - & 0.0 & 1 & 100.0 \\
\hline Ukraine & 1 & 50.0 & - & 0.0 & 1 & 50.0 \\
\hline United Kingdom & 278 & 40.2 & 190 & 27.5 & 224 & 32.4 \\
\hline Uruguay & - & 0.0 & - & 0.0 & 2 & 100.0 \\
\hline United States & 1192 & 36.1 & 1570 & 47.6 & 537 & 16.3 \\
\hline Venezuela & - & 0.0 & - & 0.0 & 6 & 100.0 \\
\hline Vietnam & - & 0.0 & - & 0.0 & 2 & 100.0 \\
\hline Yugoslavia & 2 & 25.0 & 1 & 12.5 & 5 & 62.5 \\
\hline Zambia & - & 0.0 & - & 0.0 & 1 & 100.0 \\
\hline Zimbabwe & 1 & 100.0 & - & 0.0 & - & 0.0 \\
\hline
\end{tabular}

the $10.5 \%$ of all articles published in 1992 practically doubling by 2001 to $20.9 \%$.

Table 3 shows the collaborative profile of each country. Close inspection of the table reveals certain fairly definite patterns. Countries that can be considered traditional powers in research collaborated with others in 30-35\% of the articles they generated. This was the case for Australia, Belgium, Canada, Denmark, Finland, Germany, Italy, The Netherlands, Sweden, and the United Kingdom. Next, countries such as Spain, Austria, or New Zealand related with others in about $50 \%$ of their articles. Mexico, Brazil, Croatia, Russia, and Greece do so in $60-70 \%$ of their articles, and the scientifically less developed countries do so in practically all of their articles. Thus, in general, there was an inverse relation between production and 
international collaboration in that, when production was high, the proportion of articles involving collaboration was lower, and vice versa. Finally, some countries had levels of collaboration difficult to classify, for example, Japan and the United States, for which international collaboration was lower than would have been expected, less than $20 \%$, although collaboration between their own institutions was higher, accounting for almost half the total production. Other cases include Israel, with a small percentage of international collaboration (13.6\%), Asian countries, with high production (Singapore and Taiwan) with around 20\%, China, which collaborates with other countries in over $80 \%$ of its articles, or India which, in addition to generating most of its articles without external cooperation, presents an extremely high percentage of articles with no collaboration at all $(62.5 \%)$.

Table 4 presents statistically significant proximity indices (ie, indicative of collaboration higher than the expected value). The results shown in table 4 , and a detailed examination of the relationships between all the countries under study, revealed the existence of a series of collaboration "nuclei", which we have summarized in table 5.

\section{Discussion}

The first key point of our study is that it has identified the journals that can provide a representative sample of international scientific production related to occupational health. In this sense, the two existing precedents that can be found in the literature, the studies by McCunney et al (15) and Takahashi et al (13), although based on different selection criteria, largely agree with our choice. McCunney et al chose six journals, the same ones that we used except for AIHAJ and Ann Occup Hyg. Takahashi et al chose eight journals, seven of which coincide with journals used by us, and interchanging Ann Occup Hyg for Occupational Medicine (Oxford). The selected sample does not cover the whole area of occupational health, although we think that, for the enunciated objectives, it is remarkable.

Our study has been able to characterize scientific production in occupational health. In absolute terms, domination by the United States is observed, unarguably the principal producer, appearing in almost two of every five articles. It is followed, although at some distance, by the United Kingdom and Sweden. The presence of Scandinavian countries is extremely evident, participating in almost one in every five articles. However, the results referring to these countries could be overdimensioned, given that it is precisely these countries that published most of the journals included in the analysis. In any case, this fact demonstrates the interest they have in this field. Furthermore, this over dimensioning is unequal for the three main producers. The United States participated in $43.6 \%$ of the total production but published $54.5 \%$ of the articles studied. The United Kingdom, with a participation rate of $9.2 \%$, published $23.9 \%$ of the articles. The Scandinavian countries, with a participation rate of $17.9 \%$, published 9.7\%. The fact that Scandinavian production is significantly higher than the number of articles published by its journal confirms the excellent penetration into journals published in other countries. Indeed, with respect to total Scandinavian production, $71.3 \%$ of the articles were published in American, British or German journals. In contrast the proportion of articles published outside the country of origin was $17.3 \%$ for the United States and $11.6 \%$ for the United Kingdom. These results suggest that, if there is a degree of over dimensioning, it affects the United States and the United Kingdom more than the Scandinavian countries.

Another aspect that has been observed is the need to correct absolute production by relating it to some factor to ensure comparability between countries. The country rankings by number of articles per inhabitant and articles per GDP differ from those based on absolute production. The unquestionable domination, without correction, of the United States disappears, to leave the Scandinavian countries as the main producers. In the case of correction for population size, the Scandinavian countries occupy the first five ranking positions. With GDP correction, they are still among the first ten. Thus they must be considered the countries with the greatest weight, and the high absolute and relative numbers of articles confirms their production capacity and interest in the field. The United States, on the other hand, ranks well below them when these correcting factors are applied, with a production 7.5 times lower than Sweden for articles per inhabitant and over 9 times lower than Finland if the GDP is taken into account. Other countries that maintain leading positions are The Netherlands, Canada, and the United Kingdom. Yet others have experienced an important increase, due to the fact that their small population or their GDP hide a notable production in the field. This is particularly the case for Estonia and Bulgaria, and to a less extent for Croatia and Israel. When the GDP effects are removed, Nicaragua heads the list. It would have also been interesting to use correction factors referring to the research capacity of each country, such as number of researchers, investment in research, and the like. Unfortunately this approach could not be used since the needed information was not available for all the countries studied.

With regard to collaboration, we found that the mean number of authors, and the mean number of institutions as well, per article increased over the 10-year period. This trend suggests a rise in collaboration, and such a change is confirmed when we note that the indicator of collaboration has indeed tended to rise, due mainly to the fact that international collaboration practically doubled over 
Table 4. Relationships between countries-proximity index $(\mathrm{PI})$ and its corresponding interval of confidence $(95 \%)$. [AFR $=0$ other Africa, ${ }^{\mathrm{a}} \mathrm{ASA}=$ Arab States (Asia), ${ }^{\mathrm{b}} \mathrm{ASI}=$ other Asia, ${ }^{\mathrm{c}} \mathrm{ECE}=$ central and eastern Europe, ${ }^{\mathrm{d}} \mathrm{EUR}=$ other Europe, ${ }^{\mathrm{e}} \mathrm{LAC}=$ Latin America and the Caribbean, ${ }^{\dagger} \mathrm{NIE}=$ newly industialized economies in Asia, ${ }^{g} \mathrm{PRC}=$ Peoples Republic of China, $\mathrm{SME}=$ southern Mediterranean, ${ }^{\mathrm{h}}$ UK $=\mathrm{Un}$ ited Kingdom, USA = United States]

\begin{tabular}{|c|c|c|c|c|c|c|c|c|c|}
\hline \multirow[t]{3}{*}{ Country } & \multicolumn{9}{|c|}{ Related countries } \\
\hline & \multicolumn{3}{|c|}{ Proximity index $1>4$} & \multicolumn{3}{|c|}{ Proximity index between 2 and 4} & \multicolumn{3}{|c|}{ Proximity index between 1 and 2} \\
\hline & Country & $\mathrm{Pl}$ & $95 \% \mathrm{Cl}$ & Country & PI & $95 \% \mathrm{Cl}$ & Country & PI & $95 \% \mathrm{Cl}$ \\
\hline Australia & $\begin{array}{l}\text { New Zealand } \\
\text { South Africa } \\
\text { Austria }\end{array}$ & $\begin{array}{r}11.76 \\
9.95 \\
6.25\end{array}$ & $\begin{array}{l}7.21-19.20 \\
3.73-26.51 \\
3.25-12.02\end{array}$ & UK & 2.68 & $2.30-3.11$ & . & $\cdot$ & . \\
\hline Austria & $\begin{array}{l}\text { Croatia } \\
\text { Australia } \\
\text { Germany }\end{array}$ & $\begin{array}{l}8.72 \\
6.25 \\
4.63\end{array}$ & $\begin{array}{c}4.54-16.77 \\
3.25-12.02 \\
3.81-5.64\end{array}$ & · & · & $\cdot$ & $\cdot$ & $\cdot$ & . \\
\hline Belgium & Switzerland & 5.41 & $3.66-8.01$ & $\begin{array}{l}\text { The Netherlands } \\
\text { Germany }\end{array}$ & $\begin{array}{l}3.38 \\
2.03\end{array}$ & $\begin{array}{l}2.83-4.04 \\
1.59-2.59\end{array}$ & $\begin{array}{l}\text { Spain } \\
\text { Italy } \\
\text { UK }\end{array}$ & $\begin{array}{l}1.92 \\
1.71 \\
1.53\end{array}$ & $\begin{array}{l}1.18-3.13 \\
1.34-2.19 \\
1.23-1.90\end{array}$ \\
\hline Brazil & UK & 4.44 & $3.21-6.16$ & $\cdot$ & $\cdot$ & . & . & . & . \\
\hline Canada & . & . & . & $\begin{array}{l}\text { South Africa } \\
\text { USA } \\
\text { Taiwan }\end{array}$ & $\begin{array}{l}3.44 \\
2.24 \\
2.11\end{array}$ & $\begin{array}{l}1.79-6.61 \\
2.19-2.28 \\
1.10-4.06\end{array}$ & France & 1.57 & $1.46-1.69$ \\
\hline Croatia & $\begin{array}{l}\text { Austria } \\
\text { USA }\end{array}$ & $\begin{array}{l}8.72 \\
4.93\end{array}$ & $\begin{array}{c}4.54-16.77 \\
4.67-5.20\end{array}$ & $\cdot$ & $\cdot$ & . & . & $\cdot$ & . \\
\hline Czech Republic & ECE $^{d}$ & 18.13 & $9.43-34.85$ & Sweden & 2.41 & $1.25-4.63$ & . & . & . \\
\hline Denmark & . & . & . & $\begin{array}{l}\text { Norway } \\
\text { Greece }\end{array}$ & $\begin{array}{l}2.29 \\
2.20\end{array}$ & $\begin{array}{l}2.03-2.59 \\
1.15-4.24\end{array}$ & $\begin{array}{l}\text { Italy } \\
\text { The Netherlands } \\
\text { Finland } \\
\text { UK } \\
\text { France } \\
\text { Sweden } \\
\text { Germany }\end{array}$ & $\begin{array}{l}1.75 \\
1.55 \\
1.48 \\
1.33 \\
1.31 \\
1.21 \\
1.20\end{array}$ & $\begin{array}{l}1.62-1.89 \\
1.33-1.75 \\
1.34-1.63 \\
1.23-1.44 \\
1.18-1.44 \\
1.11-1.33 \\
1.05-1.36\end{array}$ \\
\hline France & . & . & . & Norway & 2.28 & $2.06-2.51$ & $\begin{array}{l}\text { Sweden } \\
\text { ECEd } \\
\text { Poland } \\
\text { Denmark } \\
\text { France } \\
\text { Spain } \\
\text { Spain }\end{array}$ & $\begin{array}{l}1.89 \\
1.73 \\
1.67 \\
1.48 \\
1.40 \\
1.32 \\
1.91\end{array}$ & $\begin{array}{l}1.80-1.98 \\
1.17-2.56 \\
1.03-2.73 \\
1.34-1.63 \\
1.30-1.51 \\
1.11-1.58 \\
1.71-2.13\end{array}$ \\
\hline & & & & & & & $\begin{array}{l}\text { Italy } \\
\text { LAC }^{\dagger} \\
\text { Switzerland } \\
\text { Canada } \\
\text { Finland } \\
\text { Denmark } \\
\text { Sweden }\end{array}$ & $\begin{array}{l}1.75 \\
1.69 \\
1.68 \\
1.57 \\
1.40 \\
1.31 \\
1.18\end{array}$ & $\begin{array}{l}1.66-1.85 \\
1.22-2.35 \\
1.27-2.22 \\
1.46-1.69 \\
1.30-1.51 \\
1.18-1.44 \\
1.10-1.26\end{array}$ \\
\hline Germany & Austria & 4.63 & $3.81-5.64$ & $\begin{array}{l}\text { Greece } \\
\text { Switzerland } \\
\text { Belgium }\end{array}$ & $\begin{array}{l}2.52 \\
2.04 \\
2.03\end{array}$ & $\begin{array}{l}1.54-4.11 \\
1.55-2.70 \\
1.59-2.59\end{array}$ & $\begin{array}{l}\text { Spain } \\
\text { Poland } \\
\text { Denmark } \\
\text { Italy }\end{array}$ & $\begin{array}{l}1.81 \\
1.81 \\
1.20 \\
1.15\end{array}$ & $\begin{array}{l}1.58-2.09 \\
1.11-2.95 \\
1.05-1.36 \\
1.05-1.27\end{array}$ \\
\hline Greece & . & . & . & $\begin{array}{l}\text { Germany } \\
\text { Denmark }\end{array}$ & $\begin{array}{l}2.52 \\
2.20\end{array}$ & $\begin{array}{l}1.54-4.11 \\
1.15-4.24\end{array}$ & . & $\cdot$ & . \\
\hline Italy & . & . & . & . & . & . & $\begin{array}{l}\text { Spain } \\
\text { France } \\
\text { Denmark } \\
\text { Italy } \\
\text { Sweden } \\
\text { UK } \\
\text { The Netherlands } \\
\text { Germany }\end{array}$ & $\begin{array}{l}1.86 \\
1.75 \\
1.75 \\
1.71 \\
1.26 \\
1.24 \\
1.19 \\
1.15\end{array}$ & $\begin{array}{l}1.66-2.09 \\
1.66-1.85 \\
1.62-1.89 \\
1.34-2.19 \\
1.18-1.34 \\
1.16-1.32 \\
1.06-1.34 \\
1.05-1.27\end{array}$ \\
\hline Japan & $\begin{array}{l}\text { South Korea } \\
\text { NIE }^{g} \\
\text { PRC } \\
\text { ASIc }\end{array}$ & $\begin{array}{r}15.43 \\
10.62 \\
9.92 \\
5.04\end{array}$ & $\begin{array}{c}13.10-18.17 \\
3.98-28.28 \\
9.11-10.81 \\
1.89-13.44\end{array}$ & . & . & . & . & . & . \\
\hline Mexico & $\begin{array}{l}\text { LAC }^{f} \\
\text { USA }\end{array}$ & $\begin{array}{l}7.41 \\
4.69\end{array}$ & $\begin{array}{c}2.78-19.73 \\
4.26-5.18\end{array}$ & . & . & $\cdot$ & $\cdot$ & . & (con \\
\hline
\end{tabular}


Table 4. Continued.

\begin{tabular}{|c|c|c|c|c|c|c|c|c|c|}
\hline \multirow[t]{3}{*}{ Country } & \multicolumn{9}{|c|}{ Related countries } \\
\hline & \multicolumn{3}{|c|}{ Proximity index $\mid>4$} & \multicolumn{3}{|c|}{ Proximity index between 2 and 4} & \multicolumn{3}{|c|}{ Proximity index between 1 and 2} \\
\hline & Country & $\mathrm{PI}$ & $95 \% \mathrm{Cl}$ & Country & $\mathrm{PI}$ & $95 \% \mathrm{Cl}$ & Country & $\mathrm{PI}$ & $95 \% \mathrm{Cl}$ \\
\hline The Netherlands & . & . & . & $\begin{array}{l}\text { AFR a } \\
\text { Belgium } \\
\text { New Zealand }\end{array}$ & $\begin{array}{l}3.58 \\
3.38 \\
3.17\end{array}$ & $\begin{array}{l}1.34-9.54 \\
2.83-4.04 \\
1.94-5.18\end{array}$ & $\begin{array}{l}\text { UK } \\
\text { Denmark } \\
\text { Italy }\end{array}$ & $\begin{array}{l}2.00 \\
1.55 \\
1.19\end{array}$ & $\begin{array}{l}1.89-2.11 \\
1.33-1.75 \\
1.06-1.34\end{array}$ \\
\hline New Zealand & Australia & 11.76 & $7.21-19.20$ & $\begin{array}{l}\text { The Netherlands } \\
\text { UK }\end{array}$ & $\begin{array}{l}3.17 \\
2.19\end{array}$ & $\begin{array}{l}1.94-5.18 \\
1.48-3.24\end{array}$ & . & . & . \\
\hline Norway & . & . & . & $\begin{array}{l}\text { Sweden } \\
\text { Poland } \\
\text { Denmark } \\
\text { Finland }\end{array}$ & $\begin{array}{l}2.76 \\
2.43 \\
2.29 \\
2.28\end{array}$ & $\begin{array}{l}2.59-2.94 \\
1.27-4.67 \\
2.03-2.59 \\
2.06-2.51\end{array}$ & . & . & . \\
\hline PRC & $\begin{array}{l}\text { Japan } \\
\text { NIE }^{9}\end{array}$ & $\begin{array}{l}9.92 \\
7.46\end{array}$ & $\begin{array}{l}9.11-10.81 \\
2.80-19.88\end{array}$ & $\begin{array}{l}\text { USA } \\
\text { Taiwan }\end{array}$ & $\begin{array}{l}2.90 \\
2.86\end{array}$ & $\begin{array}{l}2.81-2.99 \\
1.07-7.62\end{array}$ & . & . & . \\
\hline Poland & $\cdot$ & . & . & Norway & 2.43 & $1.27-4.67$ & $\begin{array}{l}\text { Germany } \\
\text { Finland }\end{array}$ & $\begin{array}{l}1.81 \\
1.67\end{array}$ & $\begin{array}{l}1.11-2.95 \\
1.03-2.73\end{array}$ \\
\hline Russia & ECE $^{d}$ & 12.09 & $4.54-33.21$ & Sweden & 2.41 & $1.25-4.63$ & . & . & . \\
\hline South Africa & Australia & 9.95 & $3.73-26.51$ & $\begin{array}{l}\text { Canada } \\
\text { USA }\end{array}$ & $\begin{array}{l}3.44 \\
2.47\end{array}$ & $\begin{array}{l}1.79-6.61 \\
1.87-3.27\end{array}$ & . & . & . \\
\hline South Korea & $\begin{array}{l}\text { Japan } \\
\text { Switzerland }\end{array}$ & $\begin{array}{r}15.43 \\
7.33\end{array}$ & $\begin{array}{c}13.10-18.17 \\
4.49-11.97\end{array}$ & USA & 3.01 & $2.75-3.29$ & . & . & . \\
\hline Spain & $\cdot$ & . & . & . & . & . & $\begin{array}{l}\text { Belgium } \\
\text { France } \\
\text { Italy } \\
\text { Germany } \\
\text { Finland } \\
\text { UK }\end{array}$ & $\begin{array}{l}1.92 \\
1.91 \\
1.86 \\
1.81 \\
1.32 \\
1.21\end{array}$ & $\begin{array}{l}1.18-3.13 \\
1.71-2.13 \\
1.66-2.09 \\
1.58-2.09 \\
1.11-1.58 \\
1.06-1.40\end{array}$ \\
\hline Sweden & . & . & . & $\begin{array}{l}\text { Norway } \\
\text { LAC }^{\dagger} \\
\text { Russia } \\
\text { Czech Republic }\end{array}$ & $\begin{array}{l}2.76 \\
2.50 \\
2.41 \\
2.41\end{array}$ & $\begin{array}{l}2.59-2.94 \\
2.05-3.04 \\
1.25-4.63 \\
1.25-4.63\end{array}$ & $\begin{array}{l}\text { Finland } \\
\text { ECE }^{\text {d }} \\
\text { Italy } \\
\text { Denmark } \\
\text { France }\end{array}$ & $\begin{array}{l}1.89 \\
1.63 \\
1.26 \\
1.21 \\
1.18\end{array}$ & $\begin{array}{l}1.80-1.98 \\
1.17-2.26 \\
1.18-1.34 \\
1.11-1.33 \\
1.10-1.26\end{array}$ \\
\hline Switzerland & $\begin{array}{l}\text { South Korea } \\
\text { Belgium }\end{array}$ & $\begin{array}{l}7.33 \\
5.41\end{array}$ & $\begin{array}{c}4.49-11.97 \\
3.66-8.01\end{array}$ & Germany & 2.04 & $1.55-2.70$ & France & 1.68 & $1.27-2.22$ \\
\hline Taiwan & USA & 4.55 & $4.14-4.99$ & $\begin{array}{l}\text { PRC } \\
\text { Canada }\end{array}$ & $\begin{array}{l}2.86 \\
2.11\end{array}$ & $\begin{array}{l}1.07-7.62 \\
1.10-4.06\end{array}$ & . & . & . \\
\hline UK & $\begin{array}{l}\text { ASA }^{b} \\
\text { Brazil }\end{array}$ & $\begin{array}{l}9.49 \\
4.44\end{array}$ & $\begin{array}{c}7.43-12.12 \\
3.21-6.16\end{array}$ & $\begin{array}{l}\text { Australia } \\
\text { EUR } \\
\text { New Zealand }\end{array}$ & $\begin{array}{l}2.68 \\
2.22 \\
2.19\end{array}$ & $\begin{array}{l}2.30-3.11 \\
1.16-4.27 \\
1.48-3.24\end{array}$ & $\begin{array}{l}\text { The Netherlands } \\
\text { Belgium } \\
\text { Denmark } \\
\text { Italy } \\
\text { Spain }\end{array}$ & $\begin{array}{l}2.00 \\
1.53 \\
1.33 \\
1.24 \\
1.21\end{array}$ & $\begin{array}{l}1.89-2.11 \\
1.23-1.90 \\
1.23-1.44 \\
1.16-1.32 \\
1.06-1.40\end{array}$ \\
\hline USA & $\begin{array}{l}\text { Croatia } \\
\text { Mexico } \\
\text { Taiwan }\end{array}$ & $\begin{array}{l}4.93 \\
4.69 \\
4.55\end{array}$ & $\begin{array}{l}4.67-5.20 \\
4.26-5.18 \\
4.14-4.99\end{array}$ & $\begin{array}{l}\text { SME }^{\mathrm{h}} \\
\text { South Korea } \\
\text { PRC } \\
\text { South Africa } \\
\text { Canada }\end{array}$ & $\begin{array}{l}3.56 \\
3.01 \\
2.90 \\
2.47 \\
2.24\end{array}$ & $\begin{array}{l}3.03-4.19 \\
2.75-3.29 \\
2.81-2.99 \\
1.87-3.27 \\
2.19-2.28\end{array}$ & $\mathrm{LAC}^{\dagger}$ & 1.87 & $1.66-2.09$ \\
\hline $\mathrm{ASA}^{\mathrm{b}}$ & UK & 9.49 & $7.43-12.12$ & . & . & . & . & . & . \\
\hline $\mathrm{ECE}^{\mathrm{d}}$ & $\begin{array}{l}\text { Czech Republic } \\
\text { Russia }\end{array}$ & $\begin{array}{l}18.13 \\
12.09\end{array}$ & $\begin{array}{l}9.43-34.85 \\
4.54-33.21\end{array}$ & . & . & . & $\begin{array}{l}\text { Finland } \\
\text { Sweden }\end{array}$ & $\begin{array}{l}1.73 \\
1.63\end{array}$ & $\begin{array}{l}1.17-2.56 \\
1.17-2.26\end{array}$ \\
\hline $\operatorname{LAC}^{\dagger}$ & Mexico & 7.41 & $2.78-19.73$ & Sweden & 2.50 & $2.05-3.04$ & $\begin{array}{l}\text { USA } \\
\text { France }\end{array}$ & $\begin{array}{l}1.87 \\
1.69\end{array}$ & $\begin{array}{l}1.66-2.09 \\
1.22-2.35\end{array}$ \\
\hline $\mathrm{NIE}^{9}$ & $\begin{array}{l}\text { Japan } \\
\text { PRC }\end{array}$ & $\begin{array}{r}10.62 \\
7.46\end{array}$ & $\begin{array}{l}3.98-28.28 \\
2.80-19.88\end{array}$ & . & . & . & . & . & . \\
\hline $\mathrm{AFR}^{\mathrm{a}}$ & The Netherlands & 3.58 & $1.34-9.54$ & . & . & . & . & . & . \\
\hline $\mathrm{ASI}^{\circ}$ & Japan & 5.04 & $1.89-13.44$ & . & . & . & . & . & . \\
\hline EURe $^{2}$ & UK & 2.22 & $1.16-4.27$ & . & . & . & . & . & . \\
\hline SME $^{\mathrm{h}}$ & USA & 3.56 & $3.03-4.19$ & . & . & . & . & . & . \\
\hline
\end{tabular}

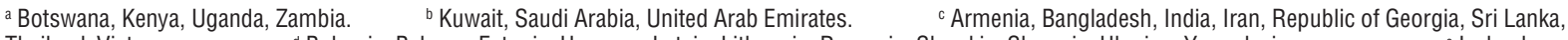
$\begin{array}{lrl}\text { Thailand, Vietnam. } & \text { d Bulgaria, Belarus, Estonia, Hungary, Latvia, Lithuania, Romania, Slovakia, Slovenia, Ukraine, Yugoslavia. } & \text { e Iceland, } \\ \text { Ireland, Portugal. } & \text { 'Argentina, Barbados, Chile, Colombia, Costa Rica, Cuba, Ecuador, French Guiana, Nicaragua, Uruguay, Venezuela. } & 9 \text { Indonesia, }\end{array}$ Hong Kong, Singapore. $\quad{ }^{h}$ Egypt, Israel, Lebanon, Turkey. 
Table 5. Identified nuclei of collaboration.

\begin{tabular}{|c|c|}
\hline Nucleus & Members \\
\hline $\begin{array}{l}\text { Asian countries, except } \\
\text { Arab states and Taiwan }\end{array}$ & $\begin{array}{l}\text { Japan, Peoples Republic of China, South } \\
\text { Korea, newly industrialized economies in Asia } \\
\text { (Indonesia, Hong Kong, Singapore), other Asia } \\
\text { (Armenia, Bangladesh, India, Iran, Republic of } \\
\text { Georgia, Sri Lanka, Thailand, Vietnam) }\end{array}$ \\
\hline Scandinavian countries & Denmark, Finland, Iceland, Norway, Sweden \\
\hline $\begin{array}{l}\text { European Union } \\
\text { countries, and } \\
\text { Switzerland }\end{array}$ & $\begin{array}{l}\text { Austria, Belgium, Denmark, France, Finland, } \\
\text { Germany, Greece, Italy, The Netherlands, } \\
\text { Spain, Switzerland, Sweden, United Kingdom, } \\
\text { other Europe (Iceland, Ireland, Portugal) }\end{array}$ \\
\hline $\begin{array}{l}\text { Central and eastern } \\
\text { Europe }\end{array}$ & $\begin{array}{l}\text { Czech Republic, Russia, central and eastern } \\
\text { Europe (Bulgaria, Belarus, Estonia, Hungary, } \\
\text { Latvia, Lithuania, Romania, Slovakia, Slovenia, } \\
\text { Ukraine, Yugoslavia) }\end{array}$ \\
\hline $\begin{array}{l}\text { Australia, New Zealand } \\
\text { and the United Kingdom }\end{array}$ & Australia, New Zealand, United Kingdom \\
\hline United States & United States \\
\hline
\end{tabular}

the period of study. This finding confirms a trend towards scientific specialization in this field.

As in studies of a general nature (20) and of a medical perspective (21), our study in occupational health found an inverse relationship between scientific production and international collaboration. It is logical to assume that the countries that produce more also have more resources available for research, not only economically speaking, but also in terms of personnel and equipment. These greater resources facilitate research without external aid or limit researchers to establishing contacts with other institutions within the same country. Less developed countries, on the other hand, may find themselves obliged to seek the resources they lack abroad. This phenomenon was clearly visible in our study. Countries with lower production achieved publication in most cases by collaborating with larger producers. This is, for example, the case of Nicaragua. All of its seven articles were written in collaboration with foreign institutions, specifically the United States and Sweden. This collaboration should be looked at in more depth in the context in which it occurs. When Nicaragua collaborates with the United States or Sweden, do they do so as equals? Could it be that, by carrying out the field work, some less developed countries are feeding the scientific production of the rich countries? Do these countries have the capacity to not only plan a study on their own, but also achieve publication of the results? In this sense, it would also be interesting to reflect on the objectives of programs of cooperation between rich and poor countries, which do not always aim at the training of qualified, independent, research personnel.

There are however countries with levels of collaboration which do not quite follow this pattern, something which could be due to the conception of science or to political factors within a country, such as international isolation, influencing the nature of relationships established by the institutions within the country.
Finally, our research has established that there are various collaboration nuclei, one of them, highly homogeneous, being formed by Japan, China, countries with newly industrialized economies, South Korea, and non-Arabic Asian countries. Significant relationships occur within the nucleus and, except for China, which has relationships with the United States and Taiwan (the latter of borderline significance), and for Korea, which relates with the United States and Switzerland, there is no relevant interchange with countries of other nuclei. The compactness of this nucleus is possibly due to cultural and linguistic factors, ways of working, and concepts of occupational health.

A second nucleus is formed by the Scandinavian countries. This is a nucleus with particular relevance, since, in addition, it is highly productive. Strong links have been established between its members, although the profiles of external collaboration vary. For example, Denmark promotes more collaboration with the block of European Union countries, whereas Sweden and Finland, although they also collaborate with some European countries, broaden their field of collaboration to other countries. Finland is a collaborator with the Baltic countries, in addition to Poland. Sweden also has relations with the central and eastern European block, especially Russia and the Czech Republic. In fact, Sweden is the Scandinavian country that collaborates in the greatest number of zones. Apart from those already mentioned, it is also an important collaborator of Latin-American countries, particularly the poorer ones: Nicaragua, Costa Rica, Ecuador, and Venezuela, as well as Chile. Norway, on the other hand, relates exclusively with members of the nucleus and Poland, having no links with other countries. Not belonging to the European Union could, in part, explain this situation.

The (fifteen) European Union countries plus Switzerland form another nucleus, which is not as homogeneous as the others, having numerous relationships between countries, although of less intensity than those in the Asian or Scandinavian nuclei. The sheer number of collaboration programs undertaken by the European Union probably explains this phenomenon. Among the relationships observed for this block, some stand out, mainly with countries that are themselves close, Germany with Austria, Belgium with Switzerland, and The Netherlands with Belgium. A Mediterranean axis, France-Spain-Italy is also hinted at. Furthermore, there is a visible lack of relationships between the "big" countries such as Germany, France and the United Kingdom, perhaps due to a policy aimed at cementing relations between northern and southern countries in EU collaborative programs.

The central and eastern European countries also form a nucleus that, at the same time, integrates two subnuclei, led by Russia and the Czech Republic. These two countries relate between themselves, while the two subnuclei that they head remain independent. In this nucleus we 
find interaction between international collaboration and political factors. Russia leads the subnuclei formed by Belarus and Slovenia, while the Czech Republic leads the nucleus involving Slovakia, the Ukraine, and the Baltic countries. There is a complete lack of collaboration between the countries formerly part of Yugoslavia. The group as a whole frequently interacts with the Scandinavian countries, above all Sweden, and, in addition, the subnucleus headed by the Czech Republic interacts with Finland. Poland, although it produces the occasional article jointly with members of this nucleus, also has relationships outside, with Germany, Finland, and Norway.

Another nucleus, predictably, is that formed by Australia, New Zealand, and the United Kingdom.

Although it cannot be considered a nucleus, the United States maintains important relationships with the whole of the American continents, but, above all, with its neighbors, Canada and Mexico. We also observed its capacity for world-wide leadership in several scenarios corresponding to zones of great North American political influence: Croatia, South Korea and Taiwan, Israel and Lebanon, South Africa and China. However, there was a notable lack of relationships with the European Union. Despite having been described, in several studies $(2,6,20)$, we did not find relations between the United Kingdom and the United States.

Finally, we must mention Canada's contribution. Related with the United States, the enormous peculiarities of the latter make it difficult to classify the pair CanadaUSA as a compact collaborative nucleus. It is notable how Canada collaborates intensely with South Africa and Taiwan, as do its neighbors, as well as with France.

\section{Acknowledgments}

Our thanks to Dr Alfons González of the Faculty of Communication Sciences, Documentation Section, Universitat Autònoma de Barcelona, for his review and pertinent comments on this paper.

\section{References}

1. World Health Organization (WHO). Health for all targets: the health policy for Europe. Copenhagen: WHO Regional Office for Europe; 1993.

2. Miquel JF, Okubo Y. Structure of international collaboration in science-part II: comparisons of profiles in countries using a link indicator. Scientometrics 1994;29:271-97.

3. Barré R, Papon P. Indicadores: finalidad y límites [Indicators: purpose and limitations]. In: United Nations Educational, Scientific, and Cultural Organization (UNESCO), editor. Informe mundial sobre la ciencia [World science report]. Madrid: Santillana; 1993.
4. Bellavista J, Guardiola E, Méndez A, Bordons M. Evaluación de la investigación [Evaluation of the investigation]. Madrid: Centro de Investigaciones Sociológicas; 1997.

5. Beaver DB, Rosen R. Studies in scientific collaboration, part I: the professional origins of scientific co-authorship. Scientometrics 1998;1:65-84.

6. Luukkonen T, Tijssen RJW, Persson O, Siversten G. The measurement of international scientific collaboration. Scientometrics $1993 ; 28: 15-36$.

7. Cakalo D. The destiny of manuscripts submitted for publication in the Archives of Industrial Hygiene and Toxicology over the past 21 years. Arh Hig Rada Toksikol 1999;50:437-40.

8. Nemery B. What happens to the manuscripts that have not been accepted for publication in Occupational and Environmental Medicine?. Occup Environ Med 2001;58:604-7.

9. Gehanno JF, Thirion B. How to select publications on occupational health: the usefulness of Medline and the impact factor. Occup Environ Med 2000;57:706-9.

10. Larsson KS. The dissemination of false data through inadequate citation. J Intern Med 1995;238:445-50.

11. Simeon-Rudolf V, Kosicek M. Scientific and technical publications of the Institute of Medical Research and Occupational Health 1988-1993. Arh Hig Rada Toksikol 1995;46:359-67.

12. Radosevic-Vidacek B, Simeon-Rudolf V. Bibliographic output of the Institute for Medical Research and Occupational Health in Zagreb between 1994 and 1998. Arh Hig Rada Toksikol 1999;50:423-35.

13. Takahashi K, Hoshuyama T, Ikegami K, Itoh T, Higashi T, Okubo T. A bibliometric study of the trend in articles related to epidemiology published in occupational health journals. Occup Environ Med 1996;53:433-8.

14. Montini T, Mangurian C, Bero LA. Assessing the evidence submitted in the development of a workplace smoking regulation: the case of Maryland. Public Health Rep 2002; 117:291-8.

15. McCunney RJ, Harzbecker J. The influence of occupational medicine on general medicine: a look at the journals. J Occup Med 1992;34:279-86.

16. Yu TS, Wong TW, Tse LA, Wang XR. Overview of occupational health research in Hong Kong. Asia Pac J Public Health 2000;12:34-40.

17. Camí J, Gómez-Caridad I, Fernández MT, Cabrero A, Marrugat J, Ugena B, et al. La producción científica española en biomedicina y salud: un estudio a través del Science Citation Index (1986-1989) [Spanish scientific production in biomedicine and health: a study via the Science Citation Index (19861989)]. Barcelona: Fondo de Investigación Sanitaria-Centro de Informacion y Documentacion Cientifica-Institut Municipal d'Investigació Mèdica; 1993.

18. World Bank. World development indicators on CD-ROM. Washington (DC): The World Bank; 2003.

19. The UNESCO Institute for Statistics. The state of science and technology in the world: 1996-1997. Montreal: United Nations Educational, Scientific, and Cultural Organization (UNESCO); 2001.

20. Schubert A, Braun T. International collaboration in the sciences, 1981-1985. Scientometrics 1990;19:3-10.

21. Camí J, Suñen E, Carbó JM, Coma L. Producción Científica Española en Biomedicina y Ciencias de la Salud (1994-2000) [Spanish scientific production in biomedicine and health (1994-2000)]. Madrid: Instituto de Salud Carlos III-Fondo de Investigación Sanitaria; 2002.

Received for publication: 6 November 2003 